\title{
Religion and Workers' Associations for Decent Work in Spain
}

\author{
Miguel González-González ${ }^{1}{ }^{\mathbb{D}}$, Óscar Fernández-Álvarez ${ }^{1, * \mathbb{C}}$, Kouadio-Alexis Lally ${ }^{2}$ \\ and Sara Ouali-Fernandez ${ }^{1} \mathbb{D}$ \\ 1 Department of History, Social Anthropology, University of León, 24007 León, Spain; \\ migog@unileon.es (M.G.-G.); sara_o_f@hotmail.com (S.O.-F.) \\ 2 Departament of Sociology-Anthropologue Social, Université Peleforo Gon Coulibaly de Korhogo, \\ Abidjan BP 1424, Ivory Coast; lally_kouadio@yahoo.fr \\ * Correspondence: Oscar.fernandez@unileon.es
}

Citation: González-González,

Miguel, Óscar Fernández-Álvarez,

Kouadio-Alexis Lally, and Sara

Ouali-Fernandez. 2021. Religion and

Workers' Associations for Decent

Work in Spain. Social Sciences 10: 169.

https://doi.org/10.3390/

socsci10050169

Academic Editor: Nigel Parton

Received: 21 April 2021

Accepted: 6 May 2021

Published: 13 May 2021

Publisher's Note: MDPI stays neutral with regard to jurisdictional claims in published maps and institutional affiliations.

\begin{abstract}
This paper analyzes the role of Catholic religious organizations and worker groups in their commitment to achieve the promotion of decent working conditions. Methodologically, critical discourse analysis (CDA) and the valuation of social anthropology applied to social and political regulations are used. The results show that defending decent work means putting people at the heart of matters and considering work a fundamental right for the dignity of human life. Conclusions show that actions such as guaranteeing workers' rights, extending social protections, and promoting social dialogue are seen as essential in achieving the aim of decent work.
\end{abstract}

Keywords: anthropology; Catholic Church; decent work; workers' rights; International Labour Organization

\section{Introduction: Study Context}

Over recent years, decent work has become a global demand of concern to political leaders and business enterprises. Indeed, the majority of businesses have taken to including in their corporate statements on social responsibility details of both their responsible attitude toward the environment, linked to sustainability, and their awareness of social accountability, relating to workers' rights. The International Labour Organization (ILO) has as its priority the promotion of basic rights in the workplace, principally those related to freedom of association, trade union freedoms, the right to collective bargaining, the elimination of any form of forced labor, and the abolition of child labor and of discriminatory employment practices. It is also essential to eliminate inequalities between genders in work-related matters and to ensure that fair wages are paid (ILO 1999).

The objective of this work is to analyze the role of fundamental actors in this matter, such as the Catholic Church as a religious institution and the workers' associations linked to it, since both these social agents have among their objectives the attaining of a fairer society in which workers can earn a reasonable wage and have a respectable quality of life without suffering any kind of exploitation or discrimination. From an anthropological viewpoint, fundamental questions such as jobs, employment, pay, and the concept of decent work, which allow people to realize their human aspirations in life, are addressed.

Within the framework of this study, as an outline of a sequence of theoretical background, different perspectives and their different dimensions must be considered, starting with reflections regarding good work (Schumacher 1980) and its contemplation in society (Watson 1987), passing through the definition used in the anthropology of work (Rieznik 2001) and that used in economic anthropology (Narotzky 2004; Polanyi 2007). On this topic, the prominence of labor relations in the wellbeing of workers (Köhler and Artiles 2006) and in their workplace (De la Garza Toledo 2010) has also been considered. Fundamental factors such as benefit and salary have been analyzed throughout history and up to the present (Harvey 1998; Termes 2001), including the impact of labor reforms and unemployment (Martínez Veiga 2016). This provides us with a measure of their prominence in people's 
lives, which is such that decent work is fundamental for international organizations such as the UN (2015), ILO (2015a), and the EU (2017). In the following sections, we examine the role of workers' associations and the Church in the Spanish panorama, which have a lot to do with ethics and social justice (Zubero et al. 2007; Margalit 2010). Since the phenomenon of decent work has a significant impact on the economy and on the health of the population, the ultimate aim of this study is to contribute to the debate and to the literature on the topic in such a way that this contribution can serve as the basis for future in-depth research in this direction.

\section{Materials and Methods}

This study was carried out using what is termed critical discourse analysis (CDA), applied to information collected by different institutions, i.e., the key actors mentioned above, such as the Catholic Church and workers' associations. This method allows us, firstly, to analyze the relationship between discourse and society to observe (Van Dijk 1999, 2008) and the level of its necessity and, secondly, to establish categories of analysis to gather results.

As noted by Meyer (2001), CDA as a research approach should not be understood as a single method, but rather as a viewpoint from which various planes simultaneously acquire consistency. In this way, discourse is seen, on one hand. as a product which is able to reveal certain underlying content, worldviews, opinions, or ideologies. On the other hand, it is conceived of as an instrument which is capable of projecting such content into people's social or individual representations. A particularly striking example of this intention to unify the social and the communicative through an analysis of the linguistic can be found in the discourse strategies envisaged by the historical discourse approaches of Wodak (2002) and Weiss and Wodak (2003). This includes a reference or naming strategy in which, among the arrangements of interest, there is the categorization of belonging. Moreover, one of the basic characteristics of CDA is the need to bring together knowledge drawn from other disciplines so as to offer a full and appropriate view of its object of study, this equating to a principle of interdisciplinarity.

The adopted procedure consists of three phases. In the first, information contained in memoranda, laws, and regulations of the institutions mentioned above is traced with the intention to clarify the objectives of the research, as well as to observe the effects of regulations and their changes and interpretations. As Moragas (1997) explains, limitations to reading, or their replacement by images or interactive texts, which must necessarily be brief and synoptic, can lead to the impoverishment of debate and reflections on social realities.

At this level of media analysis, the enunciative, the thematic, and the rhetorical were sought. The sample considered comprised information contained in different documents, such as the Thesaurus of the International Labour Organization (ILO), the Secretary General's Statements of the United Nations Organization, Resolutions by the General Assembly in September 2015 (UN 2015, A/70/1), the Decent Work Agenda of the International Labour Organization, the United Nations Economic Commission for Latin America and the Caribbean (CEPAL 2013), the Guidelines for worthy employment for the period 2018 to 2020 (Gobierno de España 2018), the Progress Report of an Action Plan for implementing the 2030 Agenda (Gobierno de España 2019), the Spanish Workers' Statute, the Compendium of the Social Doctrine of the Church (Consejo Pontificio Justicia y Paz 2005), documents issued by the HOAC, Workers' Catholic Action Brotherhood (Comisión Permanente de la HOAC 2018), documents issued by the group "Church for Decent Work" (ITD 2019); Pope Francisco (2013, Evangeli Gaudium Articles 53 and 54), and the 2030 Agenda for Sustainable Development.

The second phase involved desk analysis of the information collected and allowed the elaboration of categories highlighting the recurrence of themes in the indication of values related to the objectives. In the organization of the data, political, social, or labor responsibilities, as well as age and gender were taken into account in order to guarantee 
representativeness and diversity, and so were other sociodemographic factors that may have a low incidence.

In processing the data, the thematic narrative analysis of Riessman (2008) was used in order to establish these categories more easily. Coding was completed inductively through constant comparison (Merriam 1998). In the third phase, the information was analyzed and framed within the theoretical framework of reference, leading to discussion and interpretation regarding decent work in the Spanish case, as described below, and ending with conclusions and avenues for further research on the topic in the near future.

\section{Results}

Three fundamental issues emerge from data analysis: considerations around work and employment; exchange, i.e., performing work for pay; and considerations of ILO and the European Union regarding decent work.

\subsection{Considerations on Work and Employment}

Work occupies a central place in human lives and is fundamental to social relationships and to the development of societies. This is true to such an extent that in anthropological studies, it is considered an inherent feature of human nature. Along these lines, Andrassi (2004, p. 7) stated that during the twentieth century, work attained the dignity of becoming the object of academic attention since the momentum from labor studies contributed to the development and modernization of individual countries and the whole world economy.

Since the dawn of time, humankind has undertaken work, and humans have had interchanges with nature, modifying it and placing it at their service, but also establishing relations with it. By transforming their surroundings through work, humans have transformed themselves both as individuals and as social beings. Rieznik (2001) defines work as the possibility human beings have of making their environment particularly suited to their needs-as a condition, indeed, for their very survival. Work is so important in the life of humankind that even Engels (2011), in his unfinished article "The Part Played by Labour in the Transition from Ape to Man" (1876), claimed that it is such a basic core condition for all human life that work has created humans themselves. The origin and diffusion of systems for obtaining food led to the formation of ever more complex political and social systems, and thus, the production of foodstuffs brought great changes to human life. On this point, it must be made clear that materials are not resources if people cannot use them, and it is precisely culture that identifies the elements in our surroundings that constitute resources and those that do not. In this sense, Narotzky (2004) pointed out that social relationships in production are the outcome of the manner in which co-operation, whether voluntary or forced, and co-ordination take place among those contributing in one way or another to the production process. Hence, an analysis of working procedures can aid in understanding the day-to-day experience of work. It can thus be stated that human work is multidimensional. However, the question that must be asked is what these fundamental dimensions in work are. Reviewing some of the most important classic works in political ecology, Schumacher (1980) pointed to three basic dimensions of work that may be summarized as follows: production of goods and services necessary for existence; personal fulfilment or self-realization and using and perfecting natural talents and abilities; and socialization so that collaborating with others to free oneself from self-centeredness. In this sense, we can refer to Bateson (2000), who argued that when speaking of communication as the act that makes human relationships possible, it is much more than a simple transfer of information and instead integrates multiple modes of behavior.

Its triple function offers work so central a place in human life that it is clearly impossible to conceive of life at the human level without it. It is worth quoting the views of Albert Camus (1987) on work at this point: "Sans le travail, la vie devient lamentable. Mais lorsque le travail est abrutissant la vie étouffe et se meurt" (Without work, all life goes rotten. But when work is soulless, life is stifled and dies). There is no doubt that it can be claimed that 
each of these three dimensions is problematic. Production can cause evil just as much as it can good. Human faculties can be developed in many directions, whether for good or for bad. There are perverse forms of socialization. None of this, though, invalidates the stated multidimensionality of work; it just underlines its ambiguous nature. This ambiguity, at bottom, is merely the ambiguity of all things human. Watson (1994) defined work as the carrying out of tasks that allow people to earn a living in the environment where they find themselves. By "earn a living", however, he did not mean only the production of material goods that ensure survival, but the setting of a standard of living that has a good deal to do with not just the material, but also the cultural aspects of the human experience. This is strongly linked to the comments of Maslow (1991) in his theory of the hierarchy of needs. In life, higher needs can arise that dominate the organism more than mere physiological hunger; when these are satisfied, others can emerge, and so on, successively. In relation to work and identity, Lozano and Palenzuela (2016) defined work as any action having the chief economic aim of producing goods or providing services. However, they also pointed out that work is a marker of identity, linked to the building up of behaviors and ideas, and holds a core position in people's lives. Hence, it may be argued that in this productive activity, which is fundamental as a means of subsistence for human beings, work is also a major factor in forging identity. Furthermore, work is intimately embedded into society itself and is related to all other aspects of the social order. For Polanyi (2007), work is no more than the human beings who form society, and the Earth is the natural medium in which all societies exist.

Employment is a term sometimes confused with work. Work is the economic activity a person performs, while employment is that same activity when remunerated. Thus, not all work can be considered to be employment, since if there is no pay or profit, there is no employment. Employment is a concept related to the labor market and a social norm in the Fordism stages of capitalism, and it does not include all remunerated activity, but one entailing regulation and a work relationship governed by sociopolitical controls (Köhler and Artiles 2006, p. 22). For De la Garza Toledo (2010), there is also a broader concept of work. Work is a form of interaction between people involving material and symbolic objects, implying the construction and exchange of meaning. The thesaurus of the International Labour Organization (ILO) defines work as human activities, paid or unpaid, which produce goods or services in an economy, or meet the needs of a community, or provide a person's accustomed means of livelihood. In contrast, employment is defined as work carried out in return for payment, regardless of whether there is a relationship of dependence or not. This remuneration for work is what is called pay or salary and is analyzed in the following section.

\subsection{Exchange: Performing Work for Pay}

From an etymological point of view, the general term "pay" can be traced back to the Latin verb "pacare", with the meaning of "pacify" or "satisfy", which includes the implication of somebody to whom a debt is owed. The word "salary" comes from Latin term "salarium", with the original sense of "an amount given to a soldier for the purchase of salt".

At present, in Spain, the legal concept of pay is determined in Article 26.1 of the Workers' Statute. This defines wages or salary, stating that the totality of the economic payments received by workers in cash or in kind for services rendered on behalf of another, whether in exchange for actual work, regardless of the form of compensation, or for the rest periods that can be counted as work, shall be considered to be salary. This is understood to cover workers of all genders.

As noted above, a mode of production is a way of organizing the production of things, a set of social relationships through which work effort is brought to bear. It must be kept in mind that in the capitalist system of production, money buys work effort. This means that there is frequently a split between the various agents involved in the process, specifically employers and employees. However, in non-industrial societies, work is not something 
that can be bought. It is given as a social obligation arising from family ties or mutual aid in producing items.

The topic of pay was addressed as far back as the sixteenth century by Spanish scholars such as Luis de Molina or Henrique de Villalobos, and it was seen as a matter of transactional justice. The theory of fair pay rests on willingness and free consent, to the exclusion of any form of fraud or deceit. On this point, it must be stressed, as noted by Rafael Termes (2001), that workers' needs do not determine what they are paid, same as the needs of the landlord do not determine the rent charged. A fair wage is the outcome of free negotiation between the two parties concerned. In any case, abandoning workers to private whims and market forces would equate to leaving them unprotected. In labor contexts, there are power relationships in which workers are the weaker participants, so there is the need for a legal framework to regulate these work ties. Hence, labor law establishes minimums that cannot be waived in various fields, among them remuneration, to protect workers in this asymmetrical relationship. If this were not so, workers would be turned into mere objects available for the highest bidder. Along these lines, an example may be seen in the most recent labor reform enacted by the Spanish Government on 10 February 2012, which served to give greater power to entrepreneurs. This has brought with it dire consequences for workers, such as making it simpler and easier to fire them, increasing the precariousness of jobs, lowering wages, and leading to greater instability and turnover of employees. These changes are of such an extent that, as Martínez Veiga (2016) points out, "flexibility" has become the quintessence of the capitalist spirit of post-Fordism, which rejects out of hand any sort of rigidity. Post-Fordism should be understood as the system of production that has predominated in industrialized countries since the end of the twentieth century. It is based on total flexibility in specialization, on contracting out, and on using more women in a precarious workforce. It is a neoliberal social model, described by Alonso and Fernández (2009) as characterized by the application of recipes grounded in the absolute flexibility of the workforce as a response to changes in consumption and technology. Competitiveness has led to the deregulation of economies and put a brake on social demands, triggering unemployment and precarious work.

As stated by Harvey (1998), money confers the privilege of power over others: their working time or their services can be bought, and systematic relationships of dominance over the exploited classes can even be built up merely through the power of money. In any case, in present-day developed societies, paid work plays a central role in people's lives. The income workers obtain determines their quality of life, and additionally, as noted by Watson (2002), their involvement in work is an element in the construction of their personal identity. This means that with modern societies structured as they are at present, it would be unthinkable, not to say impossible, to envisage work relationships in which pay would not be present.

\subsection{International Labour Organization and the European Union about Decent Work}

In social media, there is ever more discussion around the concept of decent work. In the Secretary General's statement on the activities of the United Nations Organization, it was pointed out that one of the main objectives must be the achievement of sustainable development through the creation of jobs and provision of decent work for everyone. One of the goals set in the Resolution adopted by the General Assembly in September 2015 (UN 2015, A/70/1) was to promote sustained, inclusive, and sustainable economic growth, full and productive employment, and decent work for all, including women and the young.

Decent work is a concept which attempts to express what ought to constitute a good job or worthy employment in today's globalized world. The words "employment" and "work" are used as if synonymous, although the second refers to a broader category of human activity than the first (Levaggi 2006). Decent work is fundamental in combating poverty and overcoming inequality. Its aim is to contribute to development by linking labor rights and social dialogue with policies for employment and social protection. Decent or worthy work allows working people to achieve their human aspirations in life, whether 
personal, vocational, or family. Levaggi (2006) even claims that there is a need for a new social contract putting people at the heart of things and not seeing work as an item of tradethis definitely being a anthropological point of view. Work that dignifies and permits the development of personal faculties is not just any old job. Work that must be done without respecting fundamental labor principles and rights is not decent work, nor is work that does not provide a fair income proportional to the efforts made, without discrimination, whether between genders or of any other type, nor is work that is completed without social protection, or with the exclusion of social dialogue and triple representation of employers, employees, and government.

Decent work (ILO 2015a) is not merely an aim but also drives sustainable development. This is stated in the 2030 Agenda for Sustainable Development. Fundamentally, decent work summarizes the aspirations of people for their working life. Decent work provides security and social protections for workers and their families thanks to a fair wage from productive employment and facilitates the equality of opportunities between men and women. Decent work increases the incomes of individuals and families which are available for spending in the local economy. This purchasing power is an incentive for growth and the development of sustainable enterprises, especially small businesses, which in turn can take on a larger number of workers and improve their pay and working conditions. Decent work increases tax revenue, so that governments can fund social measures aimed at protecting those who cannot find employment or who are unable to work. Promoting employment and enterprises, guaranteeing rights at work, extending social protections, and encouraging social dialogue are the four pillars of the ILO's Decent Work Agenda. These are indispensable factors when it comes to moving the entire Agenda for Sustainable Development forward. Decent work for all reduces inequalities and increases resilience. Policies developed through social dialogue help people and communities to tackle climate change while at the same time facilitating a transition toward a more sustainable economy. No less importantly, the dignity, hope, and sense of social justice derived from having a decent job aid in constructing and maintaining social peace (Ryder 2007).

As is well known, in 2015, all the Member States of the United Nations approved 17 Goals as part of the 2030 Agenda for Sustainable Development, which establishes a plan to achieve the Goals in 15 years. ILO (2015a) says that decent work helps to achieve all these Sustainable Development Goals. Global polls rank access to jobs as a priority, and not just any jobs but quality jobs, not just any work but decent work, because decent work means dignity, equality, a fair income, and safe working conditions. Decent work puts people at the center of development and gives women, men, and youth a voice in what they do: the right to protect themselves from exploitation and a future that is inclusive and sustainable. Decent work drives sustainable development in line with the policies proposed by workers organizations to achieve it. Those policy outcomes can be summarized as follows: more and better jobs for inclusive growth and improved youth prospects; ratification and application of international labor standards; creating and extending social protection floors; promoting sustainable enterprises; decent work in the rural economy; formalization of the informal economy; promoting workplace compliance through labor inspection; protecting workers from unacceptable forms of work; promoting fair and effective labor migration policies; and strong and representative employers 'and workers' organizations (ILO 2015a).

The European Union has not lagged behind because unemployment, competition, and the expansion of the EU from ten to twenty-eight Member States has had major repercussions for conditions of work and employment in the EU, according to the study "The Evolving World of Work in the Enlarged E.U." (Eyraud 2007). Along these lines, as far back as 2007, the Council of Ministers of the European Union approved a set of conclusions regarding promoting decent work in the EU and around the world in order to adopt policies aimed at putting into practice the innovatory force of decent, productive work that would put an end to the waste of human lives relating to the high level of unemployment and poverty among workers (ILO 2007). It should also be noted that on 8 September 2015, the European Parliament passed a resolution authorizing Member States on behalf 
of the European Union to ratify the ILO Protocol on Forced Labour as a legally binding instrument that addresses not merely protection but also prevention and compensation for victims (ILO 2015b).

With regard to Spain, the Government's Ministry of Labour, Migrations, and Social Security drew up guidelines for worthy employment for the period of 2018 to 2020 (Gobierno de España 2018). The aim of the plan is to recover workers' rights and to improve the quality of employment and working conditions, as well as combating any failure by businesses to fulfil labor or social security regulations. Furthermore, from an anthropological perspective, the plan expressly mentions the fight against exploitation in the workplace. It stresses the human drama more than the specific figures implied by this exploitation, seeing it as an abusive appropriation for personal benefit from the work of others. This can take the form of exacting longer working days than the legal maximum, not paying a fair wage, imposing precarious work, and committing tax or social security fraud, such as paying part of wages in "brown envelope money" that is not declared. Similarly, implementation of the 2030 Agenda in Spain has taken concrete shape in a Progress Report relating to the Spanish Cabinet's approval on 29 June 2018 of an Action Plan for implementing the 2030 Agenda (Gobierno de España 2019). This Progress Report is of considerable weight in the area being discussed here. It has as its direct aim to prevent and combat poverty, inequality, and social exclusion, of particular note being the increase in the national minimum wage, a measure intended to avoid poverty among those in work. It also aims at enhancing the living standards of wage earners, including women and the young, and encouraging a more dynamic growth in pay levels. These measures should be highlighted, as they are a route toward decent work, which, as already noted, should ensure security and social protection for workers and their families. This should do away with the phenomenon of "impoverished workers" who, despite being in employment, find that they cannot make ends meet because their pay is not enough to cover their living expenses, let alone allow them to build up a nest egg of savings. As Sader (2008) claims, it is not technology that puts workers out of a job; rather, it is whoever takes control of technological developments, which can be used equally well to reduce the length of the working day or to increase the profits creamed off by entrepreneurs. The promotion of precarious work has had an influence on the shape of labor relations, causing greater heterogeneity without in any way becoming a force for defending the basic rights of workers around the world.

Another topic of considerable social concern is inequality between genders, which should be seen as a cross-cutting issue. In the report on decent work and gender equality issued by the United Nations Economic Commission for Latin America and the Caribbean in 2013 (CEPAL 2013), it is stated that inequalities between genders are a direct consequence of traditional cultural views about the place and role that should be assigned to women in society. Overcoming these problems involves investing in gender equality and guaranteeing women's financial independence. Similarly, when speaking of equality, it is necessary to mention the inequality and exclusion affecting various different human groupings, whether on the basis of gender or of other reasons: ethnic, racial, political, or religious, among others (Abramo 2006). Aspects such as part-time work, pay gaps, higher levels of unemployment, vertical and horizontal segregation, or greater poverty, affecting women disproportionately, are matters that are still unresolved. In addition, women bear the burden of activities traditionally assigned to their gender, not to mention their role in raising families, which tend to render women's work less visible.

Watson (1987, p. 97) states that work is the carrying out of tasks allowing people to earn a living in the contexts in which they live. However, there is no doubt that this should extend to covering not merely material aspects limited to basic subsistence, but also to the cultural and leisure side of life. The definition of decent work, as is seen later on, goes considerably further, since it is not merely a question of earning pay, but of a fair wage, and with regard to the environment, the intention must be for work to be sustainable and respectful of the surroundings in which humans live. 
In his report, "Decent Work” (Somavía 1999), Juan Somavía, the first Director General of the ILO to come from the Southern Hemisphere, introduced this topic. It was characterized by four strategic objectives: rights at work, opportunities for employment, social protection, and social dialogue. Each of these also has a function in achieving broader aims, such as social inclusion, eradication of poverty, strengthening democracy, integrated development, and personal fulfilment. He also wrote of a new social conscience emerging from developments in systems of technology and production that have given rise to a new way of seeing personal identity and human rights. Specifically, in addressing human rights, the document also underlines how important it is for the ILO to concentrate its efforts on promoting fundamental workers' rights, freedom of association, free trade unions, and the right to collective bargaining. It must also aim at eliminating any form of forced labor, intensifying the fight against child labor, and bringing an end to discrimination in employment and jobs, thus promoting the enhancement of human dignity and social justice.

\section{Discussion: Catholic Church and Workers' Associations with Regard Decent Work in Spain}

Bringing together under one heading the role of the Church and that of workers' associations and trade unions may be surprising at first sight, since their aims, concerns, and approaches may seem to differ. However, with regard to the question of decent work, upon investigation, the points in common between these two groups are much greater than might be surmised at first glance.

Zubero et al. (2007), considering this topic, stated that decent work should be a job in which rights are guaranteed and which includes productive, high-quality work, basically along the lines historically defended by workers' movements when speaking of fair and worthy work. Taking as a starting point the philosophical idea put forward by Margalit (2010) that a decent society is one that does not humiliate its members and whose members do not humiliate one another, Zubero et al. (2007) held that the institutionalized humiliation found today in the world of work can be challenged by the idea of decency. The main problem is not that there are bad conditions for individuals, but rather that there is an institutional design for employment and work that degrades human beings. Along similar lines, the conception of work in the Compendium of the Social Doctrine of the Church (Consejo Pontificio Justicia y Paz 2005, Article 257) states that, "Work has a place of honour because it is a source of riches, or at least of the conditions for a decent life, and is, in principle, an effective instrument against poverty".

This concern regarding the role of the Church when it comes to decent work has become clear in recent years in its organization of World Days for Decent Work. In the manifesto for the World Day for Decent Work in 2019 (ITD 2019), subscribed to by organizations backing the Church's initiatives for decent work, it was noted that such work forms part of the objectives for sustainable development and is a crucial element in ensuring social justice and the cohesion of all of humanity. In 2018, the World Day used the slogan "Change the Rules". It is also significant that all the principal trade union associations, which can in no way be seen as religious, stress the need for the rules imposed by neoliberalism on the world economic system to change because they are unjust, create new, greater inequalities, and infringe workers' rights around the world and are an attack on democracy. Indeed, such workers' organizations and trade unions also participate in these World Days. In the statement issued by the largest Spanish trade union (CCOO 2018), Comisiones Obreras (Workers Commissions), for the World Day for Decent Work on 7 October 2018, the key features for guaranteeing decent work were seen as achieving high-quality employment, guaranteeing worthy employment for the young, attaining fair wages that allow a reasonable standard of living, just working conditions, an end to precarious work, acceptable pensions for today and for the future, an end to discrimination and gender-based pay gaps, and concluding a worldwide pact on migration, all of this in the context of sustainable development. A minimum wage and collective bargaining are essential in improving pay outcomes and reducing inequalities, especially for the poorest classes. This is because minimum wages decrease differentials in the lowest 
income segments, while collective bargaining ensures that pay levels will rise hand in hand with economic growth (Nieto and Carreras 2013).

In this relationship between the Church and trade unions, the main trade unions, although apparently wholly divorced from any Christian faith, have often made plain the aspects that unite them to Christian workers' movements and their organizations. By way of an example along these lines, it is worth citing Unai Sordo, the Secretary General of CCOO, who stated that although it was well known that the creation of his trade union grouping was linked to the Communist Party, this trade union had another strand that comprised Christian workers' movements and the Hermandad Obrera de Acción Católica. He further commented that his grouping had a historical relationship with such Christian associations. Moreover, Bishop García Burillo pointed to such dialogue with trade unions, stating that there was a good deal that the Church could say in unison with them. This is because, as he saw it, trade unions work for a clearly defined social purpose, as does the Church, although the latter adds a spiritual aspect. He felt that despite their different viewpoints, there were large areas of life in which they were similar and had links (Cruz 2017, Vida Nueva).

In accord with these arguments, Pope Francisco (2013, Evangeli Gaudium Articles 53 and 54) has spoken of the present day as having created a throwaway culture, which is no longer simply a matter of exploitation and oppression, but something new. It now involves total exclusion, in which the excluded are no longer a part of society, but outcasts and leftovers. As a counterpart of this, he noted that there was a culture of prosperity that deadened people and made them, almost without them being aware of it, incapable of feeling compassion at the outcry of the poor, lamenting other people's pain, and feeling the need to help them, as though all this were someone else's responsibility and not their own. Hence, it may be asked what the role of the Church and its followers would be in respect of this question of decent work. From the perspective of religious workers' associations, specifically HOAC (Hermandad Obrera de Acción Católica-Workers' Catholic Action Brotherhood), four key lines of thought and action relating to the world of work and workers have been put forward, specifically in what was approved in the thirteenth General Assembly. These guidelines refer to accompanying people through their lives and working together with them, co-operating to change mentalities, joining forces to achieve changes in institutions so that they are at the service of people's needs, and helping to construct alternative experiences of how to live and working in accordance with this new mentality (Comisión Permanente de la HOAC 2018).

Precisely to overcome this throwaway economy, Christian workers' associations, headed by HOAC, have called for a culture of coming together. Synthesizing this proposal would imply, among other things, similar issues to those already seen, incorporating, of course, Catholic spirituality: backing proposals and actions that make workers' lives worthier; stressing the importance of living up to the key features of Christian spirituality and values inspired by society that are what makes people human, and thus living in a spirit of solidarity and brotherliness; learning, and training oneself, to live in a different way; creating meeting points; calling for and encouraging institutions at the service of all, but first and foremost of the most disadvantaged; and proclaiming decent work for a decent society.

Comparison of these guidelines with those put forward by international organizations such as the ILO shows that these religious workers' organizations have, for the most part, the same approach as those taken by the ILO and trade unions in general. Logically, they do add a reference to spirituality, as this is inherent in their views and missions as organizations. In this sense, this religious dimension would cover what Maslow (1991) pointed out as needs for esteem or recognition, related to dignity and the needs for selfrealization, linked to spirituality. Finally, we should not disregard the influence that spirituality can have on health at work, the reduction of stress at work, and the usefulness of religiosity in the prevention of occupational stress and burnout, as has been demonstrated by Chirico et al. (2020), or religiosity as a right that cannot be abandoned in the workplace and regarding which a conciliation must be sought (González-González 2018). 


\section{Conclusions and Future Implications}

This article has shown how the importance of work in human life is an unquestionable fact. The interrelationship between humankind and nature, which humanity itself has modified and put at its service, is a constant throughout history. However, this relationship would appear particularly critical for the twenty-first century because of the matter of sustainability, something that has not gone unnoticed by the main international organizations such as the UNO, the ILO, or the European Union. Such sustainability must be understood not merely as development ensuring the needs of the present without compromising those of future generations. It must also address the matter of decent work, linked to the creation of jobs, social protection, workers' rights, and social dialogue. These are problems that at present concern millions of people and that were already highlighted in the UNO's 2030 Agenda for Sustainable development. Moreover, the different effects that the topics of decent work and their implications have on health should be considered. Important issues are linked to this agenda, such as the relationships between unemployment and health, inequality and health, or migration and health, among others.

The analysis shown in this investigation reveals that despite ever greater technological advances which might be able to solve problems relating to decent work, such as exploitation of workers or unemployment, the world is moving toward societies that are less fair. In them, post-Fordism based on flexible specialization, contracting out, and employing women in precarious work has taken advantage of technology and used it to increase the profits of big businesses. The preoccupations of international organizations, principally the ILO, have been made plain by initiatives aimed at decent work so as to achieve goals such as social inclusion, eradication of poverty, strengthening of democracy, and rounded development of individuals. The European Union has taken much the same line, adopting policies capable of putting into practice the innovatory forces of productive decent work. In Spain, the Government can also be seen to have similar concerns, as it has put in place a plan directed at dignified work, with the objective of restoring workers rights and combating failures to comply with labor regulations, stressing the human drama in these matters.

To conclude, this paper has investigated the relationship between the Church and organization with regard to decent work. Their common ground in areas such as fair wages or decent jobs is quite extensive, even though, in principle, the worlds of the spirit and of organized labor might appear to be poles apart. In fact, the views about work in the Church's Social Doctrine coincide fully with those of trade union organizations when advocating for high-quality employment with reasonable pay that would allow people to live a decent life. In any case, in spite of the logical differences that there may be in terms of certain approaches, it does seem clear that there is a coming together of the Church and of associations of workers and trade unions in respect of dignified employment or decent work. They both pursue fair conditions of work ever more vigorously in view of the obvious erosion of workers' rights in the current neoliberal context, which is plunging more and more people into poverty, even people who have a job.

Author Contributions: Conceptualization, M.G.-G., Ó.F.-Á., K.-A.L. and S.O.-F.; methodology, M.G.G., Ó.F.-Á., K.-A.L. and S.O.-F.; formal analysis and results, M.G.-G., Ó.F.-Á., K.-A.L. and S.O.-F.; Discussion and conclusion, M.G.-G., Ó.F.-Á., K.-A.L. and S.O.-F.; writing-original draft preparation, review and editing M.G.-G. and Ó.F.-Á. All authors have read and agreed to the published version of the manuscript.

Funding: This paper is a contribution to the research project into Clergy and Society in the NorthWest of the Iberian Peninsula from the Fifteenth to the Twenty-First Century funded by the Spanish Ministry of the Economy, Industry and Competitiveness, under reference HAR2017-82473-P.

Conflicts of Interest: The authors declare no conflict of interest. 


\section{References}

Abramo, Laís. 2006. Trabajo Decente y Equidad de Género en América Latina. Santiago de Chile: Oficina Internacional del Trabajo.

Alonso, Luis Enrique, and Carlos Fernández. 2009. El trabajo en la era posfordista: Un malestar permanente. Papeles de Relaciones Ecosociales y Cambio Global 108: 21-33.

Andrassi, Alejandro. 2004. Arbeit Macht Frei: El Trabajo y su Organización en el Fascismo (Alemania e Italia). Barcelona: Editorial el Viejo Topo.

Bateson, Gregory. 2000. Steps to an Ecology of Mind: Collected Essays in Anthropology, Psychiatry, Evolution, and Epistemology. Chicago: University of Chicago Press.

Camus, Albert. 1987. Éditorialiste à "L’Express" (mai 1955-février 1956). In Cahiers Albert Camus, 6. Paris: Galimard.

CCOO. 2018. Manifiesto: Cambiar las Reglas. Jornada Mundial por el Trabajo Decente del 7 de Octubre de 2018. Available online: https: / / cutt.ly /bdN51Xj (accessed on 10 June 2020).

CEPAL. 2013. Trabajo Decente e Igualdad de Género: Políticas para Mejorar el Acceso y la Calidad del Empleo de las Mujeres en América Latina y el Caribe. Santiago de Chile: Comisión Económica para América Latina y el Caribe and ONU Mujeres.

Chirico, Franceso, Manoj Sharma, Salvatore Zaffina, and Nicola Magnavita. 2020. Spirituality and prayer on teacher stress and burnout in an Italian cohort: A pilot, before-after controlled study. Frontiers in Psychology 10: 2933. [CrossRef] [PubMed]

Comisión Permanente de la HOAC. 2018. Trabajo digno para una sociedad decente. In Colección Cuadernos HOAC. Madrid: Ediciones HOAC, pp. 1-52.

Consejo Pontificio Justicia y Paz. 2005. Compendio de la Doctrina Social de la Iglesia. Cittá del Vaticano: Librería Editrice Vaticana.

Cruz, Rubén. 2017. Yo, Católico y Sindicalista. Vida Nueva. p. 3045. Available online: https://www.vidanuevadigital.com/2017/07/21 /yo-catolico-y-sindicalista-mmtc-pastoral-obrera / (accessed on 10 June 2020).

De la Garza Toledo, Enrique. 2010. Hacia un Concepto Ampliado de Trabajo. Del Concepto Clásico al no Clásico. Barcelona: Anthropos.

Engels, Friedrich. 2011. El papel del Trabajo en la Transformación del Mono en Hombre. Valencia: NoBooks Editorial.

EU. 2017. Reflection Paper on the Social Dimension of the EU. Bruselles: European Commision. Available online: https: / / www.europarl. europa.eu/RegData/etudes/BRIE/2017/603970/EPRS_BRI(2017)603970_EN.pdf (accessed on 15 September 2020).

Eyraud, François. 2007. The Evolving World of Work in the Enlarged EU. Geneva: International Labour Office.

Gobierno de España. 2018. Plan Director por un Trabajo Digno 2018; Madrid: Ministerio de Trabajo, Migraciones y Seguridad Social.

Gobierno de España. 2019. Informe de Progreso. La Implementación de la Agenda 2030 en España; Madrid: Ministerio de Asuntos Exteriores, Unión Europea y Cooperación.

González-González, Miguel. 2018. Reconciling spirituality and workplace: Towards a balanced proposal for occupational health. Journal of Religion and Health 57: 349-59. [CrossRef] [PubMed]

Harvey, David. 1998. La Condición de la Posmodernidad. Buenos Aires: Amorrortu.

ILO. 1999. Report of the Director-General: Decent Work. Geneva: International Labor Office Geneva.

ILO. 2007. ILO Welcomes EU Decision to Promote Decent Work for All. World of Work. The Magazine of the ILO. vol. 59, pp. 36-37. Available online: http://www.oit.org/global/about-the-ilo/newsroom/news/WCMS_080626/lang--en/index.html (accessed on 10 June 2020).

ILO. 2015a. 2030 Agenda for Sustainable Development. Genève: ILO.

ILO. 2015b. State of Decent Work in the World. World Day for Decent Work. Madrid: ILO.

ITD. 2019. Manifiesto: Frente a la indecente precariedad, trabajo decente, como Dios quiere. Jornada Mundial por el Trabajo Decente. October 7. Available online: https: / cutt.ly/sdN6wYy (accessed on 26 June 2020).

Köhler, Detlev, and Antonio Martín Artiles. 2006. Manual de la Sociología del Trabajo y de las Relaciones Laborales. Madrid: Delta Publicaciones.

Levaggi, Virgilio. 2006. Democracia y Trabajo Decente en América Latina. Lima: OIT.

Lozano, María José, and Pablo Palenzuela. 2016. Trabajo y culturas del trabajo en la globalidad hegemónica. Revista Andaluza de Antropología 11: 1-15. [CrossRef]

Margalit, Avishai. 2010. La Sociedad Decente. Barcelona: Paidós.

Martínez Veiga, Ubaldo. 2016. La reforma laboral de 2012 y el aumento del despido y desempleo en España. Revista Andaluza de Antropología 11: 44-66. [CrossRef]

Maslow, Abraham Harold. 1991. Motivación y Personalidad. Madrid: Ediciones Díaz de Santos.

Merriam, Sharan. 1998. Qualitative Research and Case Study Applications in Education. Revised and Expanded from "Case Study Research in Education". New York: John Wiley \& Sons.

Meyer, Michael. 2001. Between theory, method, and politics: Positioning of the approaches of CDA. In Methods of Critical Discourse Analysis. Edited by Ruth Wodak and Michael Meyer. London: Sage Publications, pp. 14-32.

Moragas, Miquel de. 1997. Las ciencias de la comunicación en la “Sociedad de la información". Diálogos de la Comunicación 49: $23-32$.

Narotzky, Susana. 2004. Antropología Económica. Nuevas Tendencias. Santa Cruz de Tenerife: Melusina.

Nieto, Joaquín, and Judith Carreras. 2013. Trabajo decente ante un mundo desigual. Gaceta Sindical: Reflexión y Debate 20: 113-32.

Polanyi, Karl. 2007. La Gran Transformación: Crítica del Liberalismo Económico. Barcelona: Las Ediciones de la Piqueta.

Pope Francisco. 2013. Exortación Apostólica Evangelii Gaudium, EG53. Vaticano: Tipografía Vaticana.

Riessman, Catherine Kohler. 2008. Narrative Methods for the Human Sciences. New York: Sage Publications.

Rieznik, Pablo. 2001. Trabajo, una definición antropológica. Razón y Revolución 7: 1-21.

Ryder, Guy. 2007. Making the Transition: How to Move Decent Work from Aspiration to Attainment. Brussels: ITUC-CSI. 
Sader, Emir. 2008. Refundar el Estado-Posneoliberalismo en América Latina. Buenos Aires: Ediciones CTA.

Schumacher, Ernst Friedrich. 1980. El Buen Trabajo. Barcelona: Debate.

Somavía, Juan. 1999. Memoria del Director General. In Trabajo Decente. Ginebra: OIT.

Termes, Rafael. 2001. Antropología del Capitalismo: Un Debate Abierto. Madrid: Ediciones Rialp.

UN. 2015. Memoria del Secretario General Sobre la Labor de la Organización. A/70/1. New York: Naciones Unidas.

Van Dijk, Teun A. 1999. Critical discourse analysis and conversation analysis. Discourse E Society 10: 459-60. [CrossRef]

Van Dijk, Teun A. 2008. Critical discourse analysis and nominalization: Problem or pseudo-problem? Discourse E Society 19: 821-28.

Watson, Tony. 1987. Trabajo y Sociedad. Barcelona: Hacer Editorial.

Watson, Tony. 1994. In Search of Management: Culture, Chaos and Control in Managerial Work. London: Routledge.

Watson, Tony. 2002. Professions and professionalism. Should we jump off the bandwagon, better to study where it is going? International Studies of Management and Organization 32: 93-115. [CrossRef]

Weiss, Gilbert, and Ruth Wodak. 2003. Introduction: Theory, interdisciplinarity and critical discourse analysis. In Critical Discourse Analysis. London: Palgrave Macmillan, pp. 1-32.

Wodak, Ruth. 2002. Aspects of critical discourse analysis. Zeitschrift für Angewandte Linguistik 36: 5-31.

Zubero, Imanol, Amartya Kumar Sen, and Joseph Stiglitz. 2007. Se Busca Trabajo Decente. Madrid: HOAC. 